\title{
SISTEEMDWANG IN DIE PREDIKING
}

\author{
Ds. P.C.Rule (Kroonstad)
}

Ons wil graag by hierdie geleentheid $u$ aandag bepaal by ' $n$ rigting in die prediking wat baie groot gevare inhou, vir sowel die prediking van die Woord van God aan die gemeente, asook vir die prediker en die gemeente self: Sisteemdwang in die prediking.

\section{WAT IS SISTEEMPREDIKING ?}

Ds. J. H. Velema het in 'n viertal artikels in „Kansel en Katheder" hierdie saak skerp onder die soeklig laat kom onder die tema: Sisteemprediking. Hy wys onder andere op die groot verskille in Nederland, onder reformatoriese gelowiges.... verskille wat veral tot openbaring kom op die veld van die kerk en van die prediking van die Woord van God aan die gemeentes. Die verskille op die veld van die kerk het tot gevolg dat daar nie gesamentlik opgetrek kan word nie, maar ,geskeie". Van eenheid kan daar dus geen sprake wees solank dié geskeidenheid bestaan nie.

Wat die prediking betref, is sy bevinding dat daar in die verskillende kerke self, 'n soms baie duidelike verskil op te merk is. Een van die groot verskille is wat ons kan noem die sisteemdwang in die prediking of soos hy dit noem: Sisteemprediking. Dit beteken letterlik: die prediking van 'n bepaalde sisteem, wat eintlik niks anders is nie as dat die prediking in 'n bepaalde keurslyf ingedwing word nie. Vandaar dat ons ook kan praat van sisteemdwang. Nou word "keurslyf" in die "Handwoordeboek van die Afrikaanse Taal", omskrywe as 'n borsrok of korset, d.w.s. iets wat knel, of ook in 'n bepaalde rigting kan indwing. Voorbeelde word genoem: Die keurslyf van dwingende reëls, wette, die keurslyf van die mode.

In die onderhawige saak van die sisteemprediking word die prediking onder dwang of knelling gebring deurdat die Woord nie voluit gepreek word volgens die sin en mening van die Heilige Gees nie, maar volgens 'n bepaalde sisteem wat deurlopend aan die gemeente voorgehou word. Hier te lande val dit veral op in die kringe van die Metodisme waar daar gedurig getokkel word op die snaar van die persoonlike bekering op dag en datum.

So word die Woord van God dan ingedwing in en onderwerp aan ' $n$ bepaalde sisteem, wat volgens Velema altyd twee dinge beteken: (1) Dat 'n mens 'n sg. „Kleine Bijbel” daarop nahou omdat verskillende hoofstukke en tekste eenvoudig net nie inpas in die bepaalde sisteem nie. Dit bring mee dat 'n mens in jou tekskeuse eensydig moet word. (2) Dat die preek altyd opgebou word volgens 'n bepaalde "stramien" of borduursel. Die goeie hoorder kom dan gou agter wat in elke preek aan die orde gaan kom en hoe die teks bewerk word vanuit die bepaalde beskouing van die kerk of prediker. 
ENKELE VOORBEELDE VAN SISTEEMDWANG SOOS DIT IN DIE SISTEEMPREDIKING NA VORE KOM

(1) Die Verbondsisteem - waarin elke preek 'n verbondspreek is. In die tema van die preek moet die woord verbond gereeld "oorkom, anders is dit geen preek nie.

(2) Die Kerksisteem-Hier kry die gemeente as dis gereeld Kerkpreke. In elke teks word die Kerk gesoek en die Heilige Skrif word aan die Kerkvisie van die prediker onderwerp.

(3) Die bekeringssisteem - Wat verwant is (soos reeds genoem) ran die Metodisme. Velema wys hier wél op die feit dat die e.ekering inderdaad noodsaaklik is, net soos die Verbond en die erk. Dit is immers almal Bybelse gegewens. Maar dit is ook waar dat daar meer in die Bybel staan as net ' $n$ oproep tot bekering. As die teks in hierdie skema of sisteem telkens ingedwing word, lyk dit of die preek meer afgestem word op evangelisasie as dat dit bediening van die Woord an die gemeente van die Here is.

(4) Die sg. Bevindingssisteem - Hier word die visier gestel op die prediking van God se werk in die mens. Hier moet die sondaar eers deur die Wet volkome ontdek word, verslae en uitgewerk wees voordat hy kan en mag kom tot die geloof in Christus. Daar moet dus eers in die lewe van die sondaar allerlei bevindinge wees van eie ellende, diepe sondekennis voordat daar sprake kan wees van Christus en van die geloof in Hom. 'n Belangrike opmerking van Velema met betrekking tot hierdie sisteem is hier van pas: Hier heers die dominee oor die Bybel. Hy pas en skaaf en sny aan die Bybelse verhaal om sy mening daaruit te kry. Die mening van die sisteem of van die groep. Ons sou wou byvoeg: Dit geld van elke sisteem. Dit is juis hierdie soort sny en skawe wat in die keurslyf dwing. Dan het ons inderdaad sisteemdwang.

(5) Wet-Evangelie. Velema verwys op 'n ander plek ook nog na 'n ander sisteem $\mathrm{nl}$. die verhouding, Wet-Evangelie, waar die wet aan die Evangelie altyd vooraf moet gaan. 'n Mens moet eers deur die Wet sy sondes leer ken, alvorens aan hom die Evangelie bedien kan word. Dit sluit baie nou aan by punt 3 , die bekeringssisteem.

(6) Die Roomse tradisie. C. Trimp handel in sy „De Actualiteit der prediking" oor die Roomse leer insake die tradisie ,wat al eeue lank aan die Gereformeerde teologie die Sola Scriptura (d.w.S. alleen die Skrif) as 'n sinvolle aksioma en enigste reël van die geloof betwis". Die tradisie word dus bokant die Skrif gestel. So kry ons nog 'n dwangsisteem.

\section{DIE SISTEEMDWANG IS ' $N$ VERSKRALING VAN DIE PREDIKING}

In sy Hermeneutiek van die O.T. sê prof. Helberg o.a.: „Elke preek moet die drie-enige God verkondig, in sy eenheid sowel as sy gedifferensieerdheid: Vader, Seun en Heilige Gees." Elke preek moet die doemwaardigheid van die mens aan die lig bring maar tegelykertyd ook die versoening en verlossing in Jesus Christus. 
Dit moet die mens se absolute magteloosheid in die sonde aan die lig bring, maar tegelykertyd ook sy verlossing deur die lewewekkende krag van die Gees in die daaglikse bekering.

Die preek moet ook altyd staan in die teken van die opstanding, dus van lewe, van hoop en van geloofsblydskap. Dit moet ook staan in die teken van die wederkoms van Christus, wanneer alle dinge weer goed sal wees, soos dit oorspronklik was.

Al hierdie heilsfeite gaan verlore wanneer die prediking ingewring word in 'n sisteem van prediking. Tewens dan kry jy nog meer sisteemdwang as die paar wat genoem is, veral as die prediking van die Woord bevraagteken word of dit nie te skraal is vir ons dinamiese tyd nie. Daar word gewoonlik gesê: ons het baie ander vrae, insigte, lewensvorme en -norme. Daarom moet dinge soos die kultuur, die politieke en sosiale insigte en vrae en situasies van ons tyd verkondig word. Dit moet saam die prediking help bepaal. M.a.w. nie slegs die Bybel moet gepreek word nie maar ook die politieke programme en gebeurtenisse. Verder word verandering in verskillende strukture verkondig, en baie ander dinge. $U$ voel dadelik: nou is ons weg van die kern van die preek, as bediening van die Woord van God.

$\mathrm{Ja}$ dit is so dat die Woord van God die hele lewe moet verlig, al die terreine. Maar die terreine, gebeurtenisse, politiek ens. moet nie die Woord vervang, hetsy geheel of gedeeltelik nie. Dan het ons hopeloos gefaal. Dit moet altyd bly: Sola Scriptura. Die Skrif alleen!

Hierdie soort sisteemprediking hou dus die gevaar in van Skrifverdraaiing: Dat die Skrif ingepas word in die sisteem. Dan is dit naderhand die Woord van die prediker. Dit is 'n groot gevaar vir die prediker. Dit lei tot verskraling en verarming van die geloofslewe van die gemeente.

\section{DIE WARE PREDIKING - EGTE WOORDVERKONDIGING}

Die prediker moet die Woord oorbring, bedien. Hy moet dit ontvou, uitvou of uitlê sodat die gemeente dit beter verstaan. Die gemeente moet dit in sy volle en diepe betekenis hoór. (Prof. J. J. v. d. Walt). Verder sê Van der Walt: Die uitlê van die Woord moet so wees dat van die geheel én die dele waar bly: Só spreek die HERE. Dit is egter harde werk.

Sidney Greijdanus sê: Dit verg inspanning om die Woord reg te preek (S. Greijdanus, Sola Scriptura, pg. 5). Dit vra groot verantwoordelikheid, want die prediker spreek nie namens homself nie, maar is die woordvoerder vir 'n Ander. Die prediker is ' $n$ oorbringer (trans-lator), nie maar net 'n vertaler nie, maar die oorbringer van die boodskap van God. Hy is wel gewone vertaler ook want hy vind die boodskap van die Skrif in 'n vreemde taal. Maar hy kan nie „oorbring” voordat hy die betekenis verstaan nie voordat hy die teks geïnterpreteer het nie. Verder sê Greijdanus: bediening (,administration") van die Woord verg van die bedienaar van die Woord om so suiwer as moontlik te vertaal en oor te bring (pg. 7). Prediking is ook nie maar oorbring van dogmas nie, maar 
is om die teks te laat spreek. Die doel van die prediker is sola scriptura te preek (pg. 36).

Huyser sê die volgende: „Basies is die enigste ding waartoe die bedienaar gebind is in sy prediking, die Woord van God soos geopenbaar in beide $\mathrm{Ou}$ en Nuwe Testament. (Aangehaal in S.G. Sola Scriptura, pg. 40).

Prof. V. E. d'Assonville sê („Die dwaasheid om te preek” p. 47): Ons moet terug na die Skrifgebruik waarin ons die Bybel met sy twee testamente eer as één Woord van God wat aan ons deur Jesus Christus toevertrou is en wat aan ons die Koninkryk van God open. Dit is die een en die ander en nie die een of die ander nie, vgl. Hebrs. 1:1: "Nadat God baie keer en op baie maniere in die ou tyd gespreek het tot die Vaders deur die profete, het Hy in hierdie laaste dae tot ons gespreek deur die Seun."

Uit die beskouing van die teksprediking alleen, of Skrifprediking alleen - die Sola Scriptura, mag egter nie afgelei word dat daar nou 'n soort biblisisme voorgestaan word en verkondig word nie - nee, die hele teologiese dissipline moet daartoe meewerk dat ons predikante beter en altyd beter toegerus word vir hulle dienswerk, om deur die prediking van die Woord van God weer die gemeente altyd beter toe te rus vir hulle dienswerk in die Kerk en Koninkryk van God.

Dit veronderstel verder dat soos d'Assonville tereg sê (a.w. p. 92) dat die prediker die Skrifte grondig moet ondersoek en doelbewus daarvoor tyd maak. Hy moet 'n ware Skrifgeleerde wees. En Jesus wil hê dat Sy predikers Skrifgeleerdes moet wees: „Toe sê Hy vir hulle: Daarom is elke Skrifgeleerde wat 'n leerling geword het in die Koninkryk van die hemele, soos 'n huisheer wat uit sy skat nuwe en ou dinge tevoorskyn bring" (Mat. 13:52).

Daar is maar net één pad vir die bedienaar van die Woord: Hy moet altyd vra: Wat sê die Here? Wat sê die Heilige Skrif? Wat sê die teks?

Prof. Helberg sê verder in sy Diktaat oor Hermeneutiek: Elke preek moet vra: Wat sê die teks oor God, oor Sy heiligheid en liefdevolle verbondsgemeenskap wat $\mathrm{Hy}$ beoefen. Ook moet elke preek Christusprediking bevat en Heilige Gees-prediking en die preek (teks) moet die hede ook binne die toekomsperspektief plaas. Jesus Christus is koning. Hy kom weer en sal alles uit die dood laat verrys. Hy het die laaste woord, en $\mathrm{Hy}$ is die lewe vir almal wat glo. Die verkondiging van die Woord trek dus saam in die sentrale inhoud van die Heilige Skrif: die groot dade van God in Jesus Christus. Verskraling van die inhoud van die prediking beteken ondervoeding van die gemeente, en dus agteruitgang (V.d.Walt).

Die inhoud van die ware preek is dus altyd die Woord van God: „Want die Woord van God is lewend en kragtig en skerper as enige tweesnydende swaard en dring deur tot die skeiding van siel en gees en van gewrigte en murg, en is 'n beoordelaar van die oorlegginge en gedagtes van die hart" (Hebr. 4:12). 


\section{DIT STEL HOE EISE AAN DIE PREDIKER}

Ons het reeds daarop gewys dat 'n voorvereiste is dat die prediker Skrifte grondig moet ondersoek as 'n ware Skrifgeleerde. Die eerste vereiste by die maak van 'n preek is noukeurige biddende eksegese. Die Heilige Gees moet die Woord vir die prediker oopmaak en hóm weer oopmaak vir die Woord: Eksegese vorm die basis van die preek.

Die tweede vereiste is ' $n$ getroue en gedurige omgang met die Skrif self. As ons die Skrif nie gereeld biddend bestudeer nie, sal al die geleerdheid in die wêreld van ons geen prediker maak nie. Want die teks kom uit die Woord. En die teks kry ek net as ek die Woord bestudeer. W. D. Jonker sê (Die Woord as opdrag pg. 31): As die predikant net met sy eie gedagtes op die preekstoel moet kom, is hy onderworpe aan die lot van alle voordragkunstenaars: hy moet altyd iets nuuts na vore laat kom, of hy verveel sy ,gehoor". Daarom moet daar by die gelowige, biddende omgang met die Heilige Skrif bykom ons verantwoordelikheid om self naarstiglik die Skrif te bestudeer. Die prediker mag nie versuim om der middel van wetenskaplike studie sy begrip van die boodskap van die Bybel te verdiep nie. (W. D. Jonker a.w. pg. 34, 35). En daarby kom nog wat Calvyn gesê het: "Ons moet die Skrif lees met die doel om Christus daarin te vind. Enigiemand wat hiervan afwyk, mag miskien arbei en studeer vir 'n leeftyd, maar hy sal nie tot die kennis van die waarheid kom nie. Ons moet nie dink dat ons wyser is as die wysheid van God nie." (Aangehaal deur beide proff. J. C. Coetzee en L. Floor, uit 'n artikel van HansJoachim Krans).

\section{MAAR SUIWERE BEDIENING VAN DIE WOORD BLY OPDRAG VAN GOD}

Die geloof van die gemeente word wesentlik deur die prediking van die Woord geraak. ,Elkeen wat die Naam van die Here aanroep, sal gered word. . Hoe kan hulle Hom dan aanroep in wie hulle nie geglo het nie. En hoe kan hulle in Hom glo van Wie hulle nie gehoor het nie? En hoe kan hulle hoor sonder een wat preek. En hoe kan hulle preek as hulle nie gestuur word nie?" (Rom. 10:13-15). Jy word geroep om te preek. Om die Woord te bedien.. Die Woord van die lewende God. Dit moet jou nederig stem. Ootmoedig. Klein voor God. Maar preek moet jy .... Daarmee is die groei van God se Kerk ten nouste gemoeid. Jy moet preek. Hierdie opdrag word saamgevat in 2 Tim. $4: 1-5$, veral vers 2: "Verkondig die Woord; hou aan tydig en ontydig; weerlê, bestraf, vermaan in alle lankmoedigheid en lering." d'Assonville sê in hierdie verband: „Sonder die prediking van die Woord, is die bestaan van die Kerk ondenkbaar. As God nie van die begin van die wêreld af sy Woord gespreek het nie, en as Hy nie daarmee deur die eeue voortgegaan het nie, vandag dit nog doen nie en tot aan die voleinding daarmee sal aanhou nie, dan sal daar nie so iets soos 'n kerk gewees het nie. Trouens die prediking van die Woord is die uitsluitlike middel waardeur „die Seun van God in 
die krag van die Heilige Gees vir Hom 'n gemeente wat tot die ewige lewe uitverkies is vergader, beskerm en onderhou." (H.K. Son. 21).

Toe dit juis die prediking was wat die kerk weer uit die vervalle puinhope van Rome teruggelei het, toe het hulle ook weer meteen die Goeie Herder Jesus Christus gesien. Daarom kán hulle só nadruklik verklaar: Die Seun van God vergader! Hy doen dit met Sy Woord! En die Gees werk die Woord! 'n Moeilike opdrag. Maar ook 'n heerlike voorreg. Daarom mag die bedienaar van die Woord hom nie besighou met enige sisteemdwang of -prediking wat hom weglok van die sentrale gedagte van die prediking nie.

Hy moet besig bly met die Woord van God. Daartoe kan en moet hy dankbaar gebruik maak van die hulpmiddele wat God aan hom gee in al die fasette van die teologiese dissipline. Maar hy moet altyd onthou dat al dié middele uit die Skrif kom en nie andersom nie. So mag hy nie die Etiek, Dogmatiek, Hermeneutiek, Homilitiek ens. indra in die Skrif of in sy preek nie, en dan slegs preek oor kerk, verbond, 'n bekeringsisteem of wat ookal wat hy moontlik daaruit kan haal, aan die gemeente opdis nie. Dan verskraal hy die prediking. Hy moet al hierdie middels, die teologiese vakke gebruik, om hom te help om beter, goeie, gesonde, suiwere Skrifprediking te bring. Dit moet ligbakens wees wat hom moet help om al die baie slaggate te vermy sodat hyself kan vashou ,aan die betroubare Woord wat volgens die leer is, sodat hy instaat kan wees om met die gesonde leer te vermaan sowel as om die teësprekers te weerlê" (Tit. $1: 9$ ).

Dit is God se kudde wat hy moet lei en wei met die Woord van God - die gemeente wat in die gepredikte Woord die stem van die Herder kan hoor.... en kom .... en volg.

Die hoogste doel van die prediking is dan ook die eer van God en nie die streling van die gemoedere van mense of allerlei sisteme nie. God drie-enig: Vader, Seun en Heilige Gees. Daaronder pas alles in waarop die prediking hom rig. Die einddoel is suiwer teosentries. Die opbou van die gemeente en die redding van sondaars en die oordeel van die goddelose, dien tot verheerliking van God Drie-enig.

"Syne is die heerlikheid tot in ewigheid. Amen" (Rom. $11: 36$ ).

\section{BRONNELYS}

1. Coetzee, J. C., Beginsels van die eksegese by Calvyn. (Klasdiktaat).

2. d'Assonville, V. E, Die dwaasheid om te preek, 1976, Boekhandel De Jong. Johannesburg.

3. Floor, L., Die hermeneutiek van Calvyn, In die Skriflig, Jaargang 14, Nr. 55.

4. Sidney Greijdanus, Sola Scriptura, Wedge Publishing Foundation, Toronto, Canada 1970.

5. Helberg, J. L., Hoe verklaar ons die Ou Testament (Klasdiktaat). 
6. Jonker, W D., Die Woord as opdrag, 1976, N.G. Kerkboekhandel, Pretoria.

7. Trimp, C. De actualiteit der prediking, 1971, Kamper Bijdragen XI. Uitgerij „De Vuurbaak”, Groningen.

8. Van der Walt, J. J. Preekmaakkunde. (Klasdiktaat 1978).

9. Velema, J. H., ds., Vier artikels in die reeks Kansel en katheder. 